\title{
Bamboo spine and the lungs
}

\author{
Karan Madan, Randeep Guleria
}

Department of Pulmonary Medicine and Sleep Disorders, All India Institute of Medical Sciences, New Delhi, India

\section{Correspondence to} Dr Karan Madan, drkaranmadan@gmail.com

\section{DESCRIPTION}

A 52-year-old male patient presented with a history of dry cough and shortness of breath of 3 year duration. There was a history of pain in the mid and lower back of 15 year duration. There was no history of wheezing, fever, chest pain, loss of weight or appetite. The patient had received antituberculous medications in the past, with no improvement. Sputum smears for acid fast bacilli were negative on multiple occasions.



Figure 1 Chest radiograph showing bilateral upper zone fibrocavitary/bullous changes with volume loss. The trachea is deviated to the right side and both the hila are pulled up.

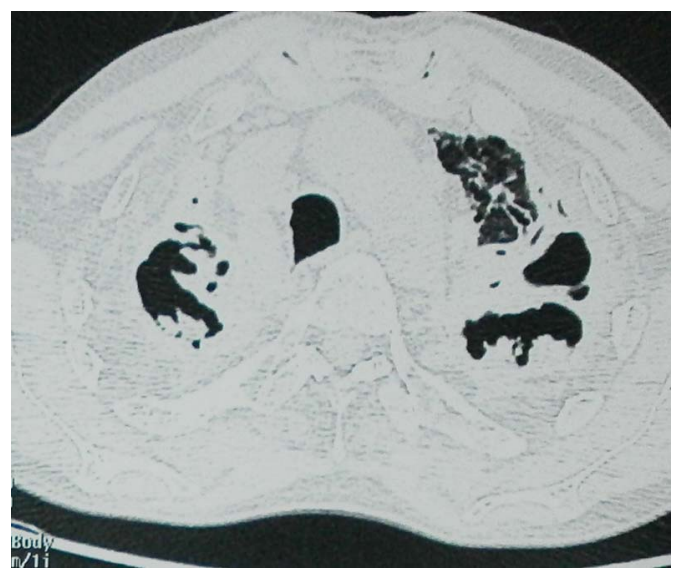

Figure 2 High-resolution CT of the thorax showing bilateral upper lobe fibrosis and cavitary changes with intracavitary-dependent soft tissue suggestive of aspergilloma.
The chest radiograph (figure 1) showed volume loss and fibrocavitary/bullous changes in the bilateral upper zones with pulled up hila. Highresolution CT of the thorax (figure 2) demonstrated fibrocavitary changes in both the upper lobes (right $>$ left), with bilateral intracavitary dependent soft tissue suggestive of a fungal ball (aspergilloma). Radiographs of the lumbosacral spine demonstrated syndesmophytes and fused vertebrae leading to a bamboo spine appearance (figure 3). Human leukocyte antigen (HLA)-B27 was positive. Diagnosis of ankylosing spondylitis (AS) with bilateral apical pulmonary fibrocystic disease was established.

The reported respiratory system complications of AS include chest wall restriction, apical fibrobullous disease with or without secondary infection (mycobacterial or fungal commonly), spontaneous

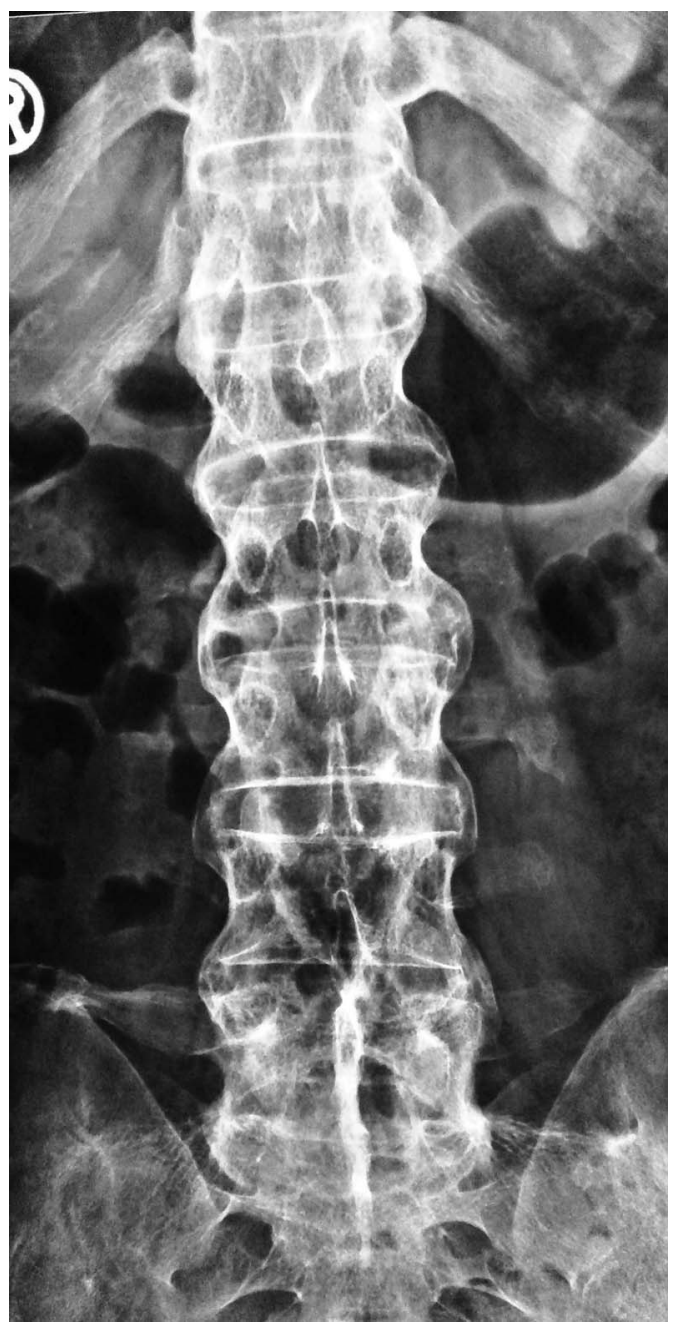

Figure 3 Radiograph of the lumbar spine demonstrating a 'bamboo spine' appearance. Syndesmophytes and vertebral fusion are seen at multiple vertebral levels. 
pneumothorax and obstructive sleep apnoea. ${ }^{1}$ Nearly $4 \%$ of patients with AS, especially men with chronic disease, develop upper lobe pulmonary fibrosis and bullous disease, the exact cause of which is not known. ${ }^{2}$ Fungal colonisation of these cavities is common. Prognosis of patients with apical fibrobullous disease is determined by the presence, extent and severity of superinfection, and no treatment has been shown to alter the clinical course of apical pulmonary disease in AS. ${ }^{1}$

\section{Learning points}

- Pulmonary complications of ankylosing spondylitis include apical fibrobullous disease with or without secondary infection, pneumothorax and chest wall restriction.

- Bilateral apical fibrobullous disease in patients with AS can closely mimic tuberculosis.

- Bamboo spine is a characteristic finding seen in patients with AS, which is a result of vertebral body fusion by syndesmophytes.
Contributors KM and RG were involved in patient management as well as in the preparation of the manuscript.

Competing interests None.

Patient consent Obtained.

Provenance and peer review Not commissioned; externally peer reviewed.

\section{REFERENCES}

1 Kanathur N, Lee-Chiong T. Pulmonary manifestations of ankylosing spondylitis. Clin Chest Med 2010;31:547-54.

2 Prakash S, Mehra NK, Bhargava S, et al. Ankylosing spondylitis in North India: a clinical and immunogenetic study. Ann Rheum Dis 1984:43:381-5.

Copyright 2013 BMJ Publishing Group. All rights reserved. For permission to reuse any of this content visit http://group.bmj.com/group/rights-licensing/permissions.

BMJ Case Report Fellows may re-use this article for personal use and teaching without any further permission.

Become a Fellow of BMJ Case Reports today and you can:

- Submit as many cases as you like

- Enjoy fast sympathetic peer review and rapid publication of accepted articles

- Access all the published articles

- Re-use any of the published material for personal use and teaching without further permission

For information on Institutional Fellowships contact consortiasales@bmjgroup.com

Visit casereports.bmj.com for more articles like this and to become a Fellow 